\title{
INFORMATION GAPS ON ORAL CANCER AND HOW SHOULD WE FILL THEM: PROPOSALS BASED ON A SURVEY OF SOUTHERN BRAZILIANS
}

\author{
LACUNAS DE INFORMAÇÃO SOBRE O CÂNCER BUCAL E COMO \\ PREENCHÊ-LAS: PROPOSTAS ENBASADAS EM PESQUISA COM SUL \\ BRASILEIROS
}

\author{
Caroline SOLDA $^{\mathbf{1}}$; Lilian RIGO ${ }^{\mathbf{2}}$; Graziela Oro CERICATO ${ }^{3}$; Raíssa Rigo GARBIN ${ }^{4}$ \\ 1. Master pos-graduate student, ULBRA, Canoas, RS, Brazil; 2.Profesor, PhD, Dentistry School, Meridional Faculty (IMED), Passo \\ Fundo, RS, Brazil; 3. Profesor, PhD, Dentistry School, Meridional Faculty (IMED), Passo Fundo, RS, Brazil. \\ graziela.cericato@imed.edu.br; 4. Doctor. Private Clinic. Passo Fundo, RS, Brazil.
}

\begin{abstract}
The purpose of this research was to ascertain the population's knowledge about oral cancer and propose permanent actions incorporated to the Primordial Prevention Measures. Materials and Methods: There were apply questionnaires in 120 patients of a Basic Health Unit, and most the sample were female and the aged was between 18-82 years. Results: The results showed that most of users don't know adequately about the oral cancer, of which, some believe it's a communicable disease, others believe it's not even a disease. Users know some of the risk factors, but they don't know how to perform self-examination of the mouth. Conclusions: It is suggested the incorporation of three new actions to Prevention Primordial Measure, including the creation of a permanent program in Elementary and Secondary Education Schools, encouraging in favor of self-examination of the mouth and against the use of tobacco and alcohol; the training of dentists from the public care about the actions of measures in Primary and Secondary Prevention; and the integration of effective communication about the actions of measures in Primary and Secondary Prevention.
\end{abstract}

KEYWORDS: Oral cancer. Knowledge. Risk factors. Health Promotion. Primary Prevention. Secondary Prevention.

\section{INTRODUCTION}

Oral cancer is a term that refers to lip cancer and oral cavity cancer (buccal mucosa, gums, hard palate, tong and floor). Around $10 \%$ of all malignant tumours of the organism occurs on the mouth (PESSÔA et al., 2015). Oral cancer, the sixth in incidence between men, the seventh between women (RAZAVI et al., 2015) and the cancer that affects more than 11.000 Brazilians every year, is the most severe disease that affects the mouth (PESSÔA et al, 2015, SOUZA et al,2015).

In Brazil, cancer is a public health problem and, for that matter, its control and prevention should be prioritized. Most of the cases are late diagnosis and public institutions conduct the most advanced cases of the disease. Most patients concentrated at stage T4 evolves to death and the survival global rate in five years is of $38,71 \%$, and the survival mean time is of 23 months, this shows the need for a more attention towards oral cancer in this population, with the intervention of heath professionals and state bodies so that can be established the early diagnosis of this neoplasias for the treatment (DAHER et al,2008). Oral cancer is curable, mostly when identified and treated since the beginning.

Therefore, we can mention successful experiences in other health areas, such as breast and prostate cancer, where extensive campaigns have been conducted to increase awareness over the need for incorporation of primary preventive measures, which are the group of actions that aim to prevent the disease, removing the causal factors, in order to reduce the incidence of the disease. In this context, the Estimate 2014 edition - Incidence of Cancer in Brazil, reference to the years 2014 and 2015, including 19 cancers (oral cavity, esophagus, stomach, colon and rectum, larynx, trachea, bronchus and lung, malignant melanoma skin, other skin malignancies, female breast, cervix, uterine body, ovarian, prostate, bladder, central nervous system, thyroid gland, Hodgkin's lymphoma, nonHodgkin lymphoma and leukemias), presents two important trends, including reduction in the incidence of new cases of cervical cancers and lung (men), results of initiatives for prevention and early detection of cervical cancer and of smoking prevention in Brazil (FACINA,2014).

The late diagnosis is related, most of the times, with one or more of the following situations: a patient that doesn't know and/or doesn't understand the gravity of the symptoms from the disease; a health professional without the capacity for the early diagnosis of oral cancer or the potential malignant disorders; and/or a local health system without the structure to assist patients with mouth 
wounds and quickly diagnose them (VELOSO et al, 2012).

Therefore, the purpose of the research was to verify the population knowledge about oral cancer and to propose permanent actions embodied to the Primordial Prevention Measures.

\section{MATERIAL AND METHODS}

The present study has quantitative approach with the delimitation of the transversal type. It was used non- probabilistic sampling, as strategy to choose the sample, to which was included all individuals that attended the ambulatory for dental care from the Basic Health Unit Adirbal Corralo, sited in the village of Victor Issler in the city of Passo Fundo, north region of the state Rio Grande do Sul, Brazil, during the months of September to November in 2013, totalizing 120 patients that consented to participate on the research. Approval for the project was obtained from the Research Ethics Committee of the Faculdade Meridional/Passo Fundo (977.842).

Data collection was performed by applying a self-administered questionnaire developed for this study and composed of 15 questions, closed, related to the sample characterization, the ideal knowledge of oral cancer, the main signals and symptoms, the usual treatment, the risk factors, the feeding, mouth's self-examination and method to perform.

The questionnaire was pre-tested before its final implementation in 10 users of the same health unit for correction and adjustment of the data collection instrument. The pre-test participants were excluded from the final sample.

The questionnaire investigation and analysis were performed using the statistical program EPIINFO. Results were expressed in tables with the frequency distribution in absolute numbers and percentages.

\section{RESULTS}

The majority of the sampling users are female $(67.5 \%)$, mean age of 50 years old, varying from 18 to 82 years old. All individuals answered not having buccal cancer during their lives (100\%).

It was observed that the majority of users don't have the appropriate knowledge about oral cancer $(89.2 \%)$. Some of those believe to be a transmitted disease $(36.7 \%)$, others don't even believe to be a disease $(2.5 \%)$. However, $(67.5 \%)$ answered that there is no pain in the first stage of the disease and that the most common signals and symptoms are the difficulty to swallow and the quick weight loss (20.8\%). Questioned about what would the users do if there were any mouth disorder for more than 15 days, most of them answered they would seek for a doctor or dentist (78.3\%).

Related to the cure, the interviewees answered that oral cancer is curable, although is necessary to stay alert and to monitor their health $(81.7 \%)$ and that the most used methods for treatment are surgery, chemotherapy, radiotherapy and psychiatry (35\%).

Related to principal risk factor for oral cancer, the users answered tobacco use (57.5\%). Besides this, the greater incidence is on men $(62.5 \%)$, on light-skinned people $(70.8 \%)$, although for most interviewees, the group age of bigger incidence was classified, with $63.4 \%$ of answers, for individuals with up to 40 year old and $56.6 \%$ for individuals older than 40 years old.

Related to the variables for prevention, it was asked with the feeding help in preventing oral cancer, where $86.7 \%$ answered yes. The chosen foods, which assisted on prevention, were fruits and vegetables $(70 \%)$.

Last the patients were questioned about selfexamination of the mouth; therefore $80 \%$ knows the exam, but believes that assist is required $(41.7 \%)$ or that dentist instrument is requested (25\%). All descriptive results of the variables are presented on Tables 1 and 2.

Table 1. Descriptive analysis of variables related to knowledge about the oral cancer, 2013.

VARIABLES N(120) \%(100)

\begin{tabular}{lcc}
\hline Knows properly oral cancer & & \\
Yes & 13 & 10.8 \\
No & 107 & 89.2 \\
Oral cancer is & 3 & \\
Not a disease & 73 & 60.5 \\
A disease. but it's not transmissible &
\end{tabular}


Oral cancer hurts in the beginning

Yes

No

Most common symptoms of Oral cancer

Difficulty speaking

Difficulty swelling

Difficulty chewing

Quick slimming

None of the above answers

What to do with a mouth wound of over 15 days

Not worry about it

Self medication

10.8

Wait longer to see if it disappears

Bless it

Seek a doctor or dentist

Table 2. Descriptive analysis of variables related about risc factors and treatment the oral cancer, 2013.

$$
\text { VARIABLES }
$$
$\%(100)$

\section{Oral cancer is curable}

It's not curable. I shall suffer forever

Yes. it's curable. but with awareness and medical 8

\section{Methods used to treat oral cancer}

Surgery

Chemotherapy

Psychiatry

Radiotherapy

5.8

All above

None above

Principal risk factors for oral cancer

Alcohol

Tobacco

Genetic inheritance

Sun exposure

Virus

Most frequent sex for oral cancer

Female

Male

Which skin color you think influences the appearance of cancer

Light skinned

Dark skinned

$4 \quad 3.3$

Any skin color

Age range among cases of oral cancer 
Feeding helps preventing oral cancer

No

Yes

Types of food that help preventing oral cancer

Fruits and vegetables

Red meat

Fat

Bread and Pasta

None

Knows what self-examination is

Yes

No

What is required for mouth self-examination

Some dental instrument

Mirror and a bright room

Someone to assist
16

104

$84 \quad 70.0$

$18 \quad 15.0$

$2 \quad 1.7$

$1 \quad 0.8$

$15 \quad 12.5$

$96 \quad 80.0$

$24 \quad 20.0$

$30 \quad 25.0$

$40 \quad 33.3$

$50 \quad 41.7$

\section{DISCUSSION}

Based on the results presented in this research, it is verified the population's lack of understanding and knowledge about the oral cancer, even though is a very ancient disease, with high incidence and a very studied one (TORRESPEREIRA et al, 2012).

On the present research, majority of participants answered not having appropriate knowledge about oral cancer. Some of them answered that oral cancer is a transmissible disease and others answered that it is not even a disease. Many studies show the lack of knowledge of population about oral cancer, about the risk factors, the preventions and about the treatment of this pathology (QUIRINO et al, 2006; OLIVEIRA et al, 2007; VIDAL et al, 2012; RAZAVI et al,2015).

Knowledge is only completely absorbed when there is effective communication, with the goal of education. Communication is a daily challenge for every people, considering that social life demands from individuals a minimum capacity of establishing intelligible dialogues, whether in professional or personal life (ALMEIDA et al, 2008). Health education must insert new habits and change the population's opinion a round relevant topics in collective health. Although, to reach the population, the methodology used by educators must be clear, accessible and with simple language, in order to transmit the scientific content and the importance of knowing and preventing grievances (ALMEIDA et al, 2008; FORMOSA et al, 2015).

When the interviewees of the present research were questioned if oral cancer caused pain, it is noticed that most of them are aware that this pathology does not present painful symptomatology in the beginning. Besides that, they described that the principal symptoms of people with the cancer is the difficulty to swallow food and great weight loss. Related to the cancer symptoms, an adequate knowledge of the requested questions was shown. In qualitative study of patients diagnosed with epidermoid carcinoma of the oral cavity it was verified that mouth symptoms such as pain and others are rarely assigned to cancer, and often interpreted as conditions of minor importance and for that reason they do not seek for professional help. The late diagnosis is strongly related with the lack of knowledge of individuals and/or lack of perception about the gravity of the symptoms of their disease (VELOSO et al, 2012).

Related to the treatment of oral cancer, some participants answered that surgery, radiotherapy, chemotherapy and psychiatry are not effective treatments, and that other methods of treatment should be used for oral cancer. Contradictory to the studies that claim treatments such as radiotherapy and chemotherapy are usually the most indicated and effective forms of treatment, precisely because it is an invasive disease with aggressive character (SERA et al, 2013). However, studies show that injuries that require mutilating treatments and that are late detected, in over $80 \%$ of cases, remains little known by the general population and bye great part of the medical and dental professional class (VELOSO et al, 2012).

Related to the determining risk factors for oral cancer, majority of interviewees believes that the cancer is most common to men. According to data about knowledge of the population of Pernambuco concerning oral cancer, male gender 
has shown to be significantly more exposed to the risk factors than women (VIDAL et al,2012).

The most prevalent group age for the occurrence of oral cancer is between the ages of 40 to 60 years old (CAMARGO-CANCELA et al,2010; GOUVEA et al, 2010; FERREIRA et al, 2012; TORRES-PEREIRA et al, 2012; VIDAL et al, 2012). Disaccording to the answers of the present study, in which most interviewees believe that the group age most prone to developing oral cancer is before 40 years old, which shows the lack of knowledge around one important risk factor for oral cancer. Studies indicate that most individuals do not have knowledge about which are the risk factors to develop oral cancer, even the ones exposed to some of the risk factors (VIDAL et al,2012). Even though, there are descriptions that the mouth malignancies would be occurring in younger populations and that could be associated to other risk factors, the epidemiologic reality majorly appoints to a patient over 40 years old, male and from a lower socioeconomic and educational stratum.

However, the main risk factors for developing oral cancer, according to the interviewees of the present study, are tobacco and after alcohol. Besides, many believe that lightskinned people are more likely to the pathology. Lip cancer is one of the most prevalent cancers that affect the mouth and it is associated to the solar exposure, whether by the ethnicity, profession or life style. In such cases, the principal preventive action is protection, trough the use of sunscreens (TORRES-PEREIRA et al., 2012). Corroborated with other studies, which show solar exposures allied with alcohol and tobacco use are the triggering and preponderant factors of the pathology (FERREIRA et al,2012; TORRES-PEREIRA et al,2012; VIDAL et al,2012). In study accomplished with patients of neck and oral cancers in a hospital of Porto Alegre, the average age was of 57,6 years old, majority male, white skin smokers, former or current and moderate or high consumption of alcohol, also from lower socioeconomic and educational level (CAMARGO-CANCELA et al,2010).

Related to the feeding, most of the sample implies that some food assist on preventing the pathology. With emphasis, fruits and vegetables as main foods that prevent oral cancer. These results are confirmed by other studies, which state the positive influence of a diet and its nutritional components in the prevention of several types of cancer, including, oral cancer, in which fruits and vegetables are the most indicated food types
(TORRES-PEREIRA et al,2012). Some of the diet elements are considered protection factors; studies associate specially B-carotene, while nutritional deficiency states are common among cases of individuals with oral cancer (LEITE E KAFMAN, 1998). However, basic foods from the Brazilian diet, like rice and beans, emerged as protection factors for the oral cancer, independent of other risk factors in case-control study on diet factors and oral cancer (MARCHIORI et al,2007).

Aiming to know the risk factors and detect early wounds, are of great importance, the Prevention Campaigns carried in Brazil focused on oral cancer. A national level campaign promoted on May of 2014 was the National Campaign of Oral cancer, called "Red May", which evolved several local sectors, besides dental surgeons, dentistry professors and undergraduate students. The primary prevention of oral cancer consists mainly in programs and actions to combat alcohol and tobacco consumption, with the intention of promoting health and reducing the referred oral grievances. The visual examination of the mouth for early detection of wounds is an important secondary prevention e of easy application, from which it is expected to diagnose the disease in its initial state (BROCKLEHURST et al,2010). The construction of informative flyers about early detection of oral cancer is valid strategy to increase the conscience and knowledge of the population about the cancer.

When the users were questioned about their understanding regarded to mouth self-examination, most of them affirmed to be aware of the subject. Nevertheless, they believe that self-examinations should be assisted by other person or some dentist tool, which means, that they do not know how to proceed it. It is known that prevention and early diagnosis are the most successful procedures to increase cancer prognosis, because prevention and the time of diagnosis represents the difference between life, survival, quality of life and death (ALMEIDA et al,2011). Health professionals, dentists and even the patient himself, wouldn't have difficulty in executing mouth examinations to visually realize suspicious changes of cancer in the mouth, because of the simple fact that the oral cavity, lips and tong are easily accessed, by visual and touch. When the pathology is detected in its early stages, it can be early diagnosed. However, most cases are late diagnosed (BROCKLEHURST et al, 2010). This way, mouth self-examination, which consist of simple techniques that the individual himself is capable of doing and with the purpose of identifying precursor wounds of cancer, 
must be stimulated for periodic implementation and not only in times of prevention campaigns.

In epidemiologic surveys made in Taubaté in the Prevention Campaigns and Early Diagnosis of Oral cancer in the years of 2001, 2003 and 2005, a low percentage of the interviewees referred to know what self-examination is. The presence of wound was the most associated situation with cancer. According to the authors, in the referred period, there wasn't consistent improve on the knowledge of people around this subject. Despite the dental organs effort to promote awareness in the population about oral cancer, there is still lot of work to be done (QUIRINO et al,2006).

In study to evaluate the knowledge level of Community Health Care Agents concerning oral cancer from specific topics, the level of knowledge was considered unsatisfactory. The topic about risk factors was the one that obtained the best performance, although, the others could have been better. The results demonstrate the imminent need of a better technical and scientific preparation of the professional for community assistance (OLIVEIRA et al, 2013). Corroborating with the study about the knowledge of dental academics, dental surgeons and lay population on buccal cancer, in which it was verified the lack of information of the people about oral cancer. Dental academics and professionals do not present ideal knowledge to disseminate prevention and early diagnostic of oral cancer (PARIZI et al, 2011).

It is of extreme importance that the development of training programs to the dental surgeons, doctors and other health professionals, especially those related to public health system. Furthermore, the dental graduates and other graduates from health courses must be better orientated according to the preventive actions for oral cancer. The programs combating oral cancer seek trough awareness and education of the population, to show the importance of performing oral examinations, education actions and of the selfexamination aiming to increase the efficiency of the oral cancer prevention e reducing the mortality rate registered in occurrence of the disease (VIDAL et al, 2012).

According to the results presented about the population knowledge on oral cancer and the scientific evidences that from years there hasn't been change on the incidence indicators and on oral cancer mortality, even though the subject is well known (TORRES-CAMARGO-CANCELA, 2010; PEREIRA et al, 2012), it is clear the need of an educational policy model that handles, first of all, the information on the pathology. Only knowledge can make an individual transform a present reality and be resolute in an issue of great population importance.

This way, from the outcomes of this research, it is suggested the incorporation of new actions to compose the Primordial Preventive Measures on the health-sick process, informing the population about the existence, the etiology, the risk and the prevention of oral cancer, which is a disease of slow evolution and lethal.

The strategic actions proposed for the change related to the indicators of this disease are, in first place, to motivate the practice of mouth selfexamination and to influence people against tobacco and alcohol consumption. These two actions are part of the programmatic content of school subjects of elementary and high school, which the theme is the knowledge on oral cancer. Education programs for health that are part of regular curriculums of elementary and high school are treated, therefore, such as formal education, affecting a specific universe of students, also considering the possibility of these students multiplying the information (ALMEIDA et al, 2011; RAZAVI et al, 2015). Second place, it is proposed the capacitation of dental surgeons aiming a better evaluation, more effectively, on the early detection of oral cancer, reinforcing the measure action for Primary and Secondary Prevention, which is determinant for public professionals. Last, the third proposal is to produce a continuous and permanent action that create and reinforce the communication with the population, involving institutions and sectors in health education activities, which would be financed by government agencies. Resembling with the suggestion of study carried to popularize oral cancer in the city of Sao Paulo, trough a communication project, which demonstrated the results of mass membership of media and communication means with national coverage. The authors demonstrated the need of planning in communication, allying multiprofessional work with specialists in marketing and communication under the supervision and theoretical basis of health professionals (ALMEIDA et al, 2011).

The importance and relevance of the proposed actions that intend reducing the grievance incidence, implying on national economy, from the reduce of government expenditures with complex treatments, this way decreasing the use of very expensive drugs and the need for hospital beds, increasingly scarce. For individual and collective benefit, according to the outcomes of the present research associated with the effectiveness of the previously proposed actions for developing 
population health, it's significant to the increase of patients' survival.

However, it is requested scientific evidence of long-rage that demonstrates the real impact of the executed actions and change in epidemiological indicators of oral cancer, at local or national level.

Among the limitations that can be listed in this study is the fact that this is a transversal study and therefore can not establish a temporal relationship between the observed associations.

\section{CONCLUSIONS}

It appears that the population does not present proper knowledge on oral cancer, not knowing its existence, with some of the interviewees considering it to be a communicable disease, and others don't even believe it is a disease.

It is suggested incorporating three new actions to the Primordial Prevention Measures, which they are, the creation of a permanent educational program in Elementary and High School, with incentive to mouth self-examination and against tobacco and alcohol consumption; the capacitation of dental surgeons from public system about the action measures of Primary and Secondary Prevention for oral cancer; and last, the insertion of effective communication on the media about oral cancer, focused to the general population, with government financing.

RESUMO: O objetivo desta pesquisa foi verificar o conhecimento da população sobre o câncer bucal e propor ações permanentes incorporados às medidas de prevenção primárias. Foram aplicados questionários em 120 usuários de uma Unidade Básica de Saúde, sendo a maioria da amostra do sexo feminine, com idade entre 18-82 anos. Os resultados mostraram que a maioria dos usuários não possui conhecimento adequado acerca do câncer bucal, dos quais, alguns acreditam que é uma doença transmissível, outros acreditam que não é uma doença. Os usuários demonstraram conhecer alguns dos fatores de risco, mas eles não sabem como realizar o auto-exame da boca. Sugere-se a incorporação de três novas ações para a prevenção Medida Primordial, incluindo a criação de um programa permanente nas Escolas em nível fundamental e Médio, incentivando a realização do auto-exame da boca e contra o uso de tabaco e álcool; a formação de dentistas do atendimento público sobre as ações de medidas em prevenção primária e secundária; e a integração de uma comunicação eficaz sobre as ações de medidas em prevenção primária e secundária.

PALAVRAS-CHAVE: Câncer de boca. Conhecimento. Fatores de risco. Promoção de saúde. Prevenção Primária. Prevenção Secundária.

\section{REFERENCES}

ALMEIDA, F. C. S.; SILVA, D. P.; AMOROSO, M. A.; DIAS, R. B.; CRIVELLO Jr, O.; ARAÚJO, M. E. Popularization of oral self-examination: an example of non-formal education - Part II. Ciência Saúde Coletiva, Rio de Janeiro, v. 16, supl 1, p. 1589-1598, jan. 2011.

ANTUNES, J. L. F.; TOPORCOV, T. N.; WÜNCH-FILHO, V. Resoluteness of the campaign for prevention and early diagnosis of oral cancer in São Paulo, Brazil. Revista Panamericana Salud Publica, Washington, v. 21, n. 1. p. 30-36, jan. 2007. http://dx.doi.org/10.1590/S1020-49892007000100004

BROCKLEHURST, P.; KUJAN, O.; GLENNY, A. M.; OLIVER, R.; SLOAN, P.; OGDEN, G.; SHEPHERD, S. Screening programmes for the early detection and prevention of oral cancer. Cochrane Database Systematic Review. London, v. 10, n. 11, CDO004150, nov. 2010.

CAMARGO-CANCELA, M.; VOTI, L.; GUERRA-YI, M.; CHAPUIS, F.; MAZUIR, M.; CURADO, M. P. Oral cavity cancer in developed and in developing countries: population-based incidence. Head Neck, Malden v. 32, n. 3, p. 357-367, mar.2010.

CUNHA, C. M.; FERREIRA, T. C.; MORALES, N. M. O.; MORALES, R. R.; PINTO, R. M. C.; SILVA, C. H. M. Influência dos tipos de cancer pediátrico e das fases do tratamento na qualidade de vida dos cuidadores. Bioscience Journal, Uberlândia, v. 29, n. 3, p. 774-780, mai/jun, 2013. 
DAHER, G. C. A.; PEREIRA, G. A.; OLIVEIRA, A. C. D. Epidemiological characteristics of cases of oral cancer registered in a hospital in Uberaba, from 1999 to 2003: a warning for the need of early diagnosis.

Revista Brasileira Epidemiologia, São Paulo, v. 11, n. 4, p. 584- 596, dez.2008.

FACINA, T. Estimativa 2014 - Incidência de Câncer no Brasil. Revista Brasileira de Cancerologia, Rio de Janeiro, v. 60, n. 1, p. 63, 2014.

FERREIRA, M. A. F.; GOMES, M. N.; MICHELS, F. A. S.; DANTAS, A. A.; LATORRE, M. R. D. Social inequality in sickness and death by oral and oropharyngeal cancer in the city of São Paulo, Brazil: from 1997 to 2008. Cadernos de Saúde Pública, Rio de Janeiro, v. 28, n. 9, p. 1663-1673, set. 2012.

FORMOSA, J.; JENNER, R.; NGUYEN-THI, M. D.; STEPHENS, C.; WILSON, C.; ARIYAWARDANA, A. Awareness and Knowledge of Oral Cancer and Potentially Malignant Oral Disorders among Dental Patients in Far North Queensland, Australia. Asian Pacific Journal of Cancer Prevention, Korea. v. 16, n. 10, p 44294434.

GOUVEA, A. S.; NOGUEIRA, M. X.; OLIVEIRA, Z. F. L.; PODESTÁ, J. R. V.; VON ZEIDLERV, S. V. Clinical and epidemiological aspects of oral cancer in an oncology hospital: prevalence of locally advanced disease. Revista Brasileira de Cirurgia de Cabeça e Pescoço, São Paulo, v. 39, n. 4, p. 261-265, out/nov.dez, 2010.

LEITE, I. C. G.; KOIFMAN, S. Review of risk factors for oral and pharynx cancer. Revista Brasileira de Cancerologia, v. 44, n. 4, p. 317-325, out/nov/dez, 1998.

MARCHIONI, D. M. L.; FISBERG, R. M.; GÓIS FILHO, J. F.; KOWLASKI, L. P.; CARVALHO, M. B.; ABRAHÃO, M.; LATORRE, M. R. D. O.; ELUF NETO, J.; WUNSCH-FILHO, V. Dietary factors and oral cancer: case-control study in the Metropolitan Region of São Paulo, Brazil. Cadernos de Saúde Pública, Rio de Janeiro, v. 23, n. 3, p. 553-564, mar. 2007.

OLIVEIRA, J. M. B.; OLIVEIRA, J. M. B.; PINTO, L. O.; LIMA, N. G. M.; ALMEIDA, G. C. M. Oral Cancer: Knowledge Assessment of Dentistry and Nursing Students regarding Risk Factors and Diagnosis Procedures. Revista Brasileira de Cancerologia, v. 59, n. 2, p. 211-218, abr/maio/jun., 2013.

PARIZI, J. L.; CASTRO, S. D.; PONGA, C. M. Q.; PARIZI, A. G. S. Knowledge of Dentistry students, Dental Surgeons, and general population on oral cancer. Revista da Associação Paulista de Cirurgiões Dentistas, São Paulo, v. 65, n. 1, p. 66-70, 2011.

PESSÔA, C. P.; ALVES, T. D.; SANTOS, N. C.;SANTOS, H. L.; AZEVEDO, A. de C.; SANTOS, J. N.; OLIVEIRA, M. C. Epidemiological survey of oral lesions in children and adolescents in a Brazilian population. International Journal of Pediatric Otorhinolaryngology, New York, v. 79, n. 11, 14, p. 1865-1871, ago. 2015.

QUIRINO, M. R. S.; GOMES, F. C.; MARCONDES, M. S.; BALDUCCI, I.; ANBINDER, A. L. Oral cancer knowledge among participants of an oral cancer prevention and screening program in Taubaté - SP. Revista Odontologia UNESP, Araraquara, v. 35, n. 4, p. 327-333, jul/ago, 2006.

RAZAVI, S. M.; TAHANI, B.; NOURI, S.; KHAZAEI, A. Oral Cancer Knowledge and Practice among Dental Patients and their Attitude Towards Tobacco Cessation in Iran. Asian Pacific Journal of Cancer Prevention, Korea. v. 16, n. 13, p. 5439-5455, 2015. http://dx.doi.org/10.7314/APJCP.2015.16.13.5439

SERA, E. A. R.; OLIVEIRA, R. V.; MARIOTTO, A. H.; AQUINO, D. R.; SCHERMA, A. P. Assessment of dental care before and during radiotherapy treatment. Brazilian Journal Periodontology, Belo Horizonte, $\mathrm{v}$. 23, n. 2, p. 30-38, 2013. 
SOUZA, M. C.; MARTINS, G.D.; PERES, M.A.; FORTES, F.L.; ALMEIDA FILHO, A.J. Symbolic effects capitalized by nurses from the National Institute of Cancer in Brazil (1980 - 1990). Revista Brasileira de Enfermagem, Brasília, v. 68, n. 2, p. 284-290, mar/abr, 2015.

TORRES-PEREIRA, C. C.; ANGELIM-DIAS, A.; MELO, N. S.; LEMOS JUNIOR, C. A.; OLIVEIRA, E. M. F. Addressing Oral Cancer: a strategy for primary and secondary health care. Cadernos de Saúde Pública, Rio de Janeiro, v. 28, Supl, p. S30-S39, 2012.

VELOSO, J. D.; RIBEIRO, C. F.; ALBUQUERQUE JUNIOR, R. L. C.; RAMALHO, L. M. P.; GUEIROS, L. A. M.; DE MELO, A. U. C. Delay in Oral Cancer Diagnosis: Understanding Related Factors. Revista Brasileira de Ciências da Saúde, João Pessoa, v. 16, n. 4, p. 579-584, 2012.

http://dx.doi.org/10.4034/RBCS.2012.16.04.13

VIDAL, A. K. L.; AGUIAR, R. D. M. A.; GOUVERIA, M. V.; CAVALCANTE NETO, P. M.; TAVARES, A. N. S.; GUIMARAENS, M. A. Verification of Population Knowledge on Oral Cancer and Risk Factors. Pesquisa Brasileira em Odontopediatria e Clínica Integrada, João Pessoa, v. 12, n. 3, p. 383-387, 2012. http://dx.doi.org/10.4034/PBOCI.2012.123.13 